\title{
Comparison of two surgical approaches for Laparoscopic Ovum Pick Up in Ewes
}

\author{
[Comparação de duas abordagens cirúrgicas para aspiração folicular \\ laparoscópica em ovelhas] \\ R.S.G. Mariano ${ }^{1}$, R.A.R. Uscategu ${ }^{2}$, R.P. Nociti ${ }^{1}$, F.F.P.C. Barros ${ }^{3}$, \\ V.J.C. Santos ${ }^{1}$, L.N. Coutinho ${ }^{4}$, L.C. Padilha-Nakaghi ${ }^{1}$, P.D.A. Silva ${ }^{1}$, \\ P.P.M. Teixeira ${ }^{5}$, W.R. R. Vicente ${ }^{1}$ \\ ${ }^{1}$ Universidade Estadual Paulista - Jaboticabal, SP \\ ${ }^{2}$ Universidade Federal dos Vales do Jequitinhonha e Mucuri - Unaí, MG \\ ${ }^{3}$ Universidade Federal Rural do Rio de Janeiro - Seropédica, RJ \\ ${ }^{4}$ Universidade Federal Rural da Amazônia - Belém, PA \\ ${ }^{5}$ Universidade Federal do Pará - Castanhal, PA
}

\begin{abstract}
The present study had as an aim to evaluate a right lateral access as an alternative method to laparoscopic ovum pick-up (LOPU) in sheep. Twenty-four Santa Ines ewes were randomly assigned in two groups with twelve animals each: RLD - positioned in right lateral decubitus, with $10^{\circ}$ head-down tilt; and DD positioned in dorsal decubitus with $35^{\circ}$ head-down tilt. The following parameters were evaluated every 10 minutes during the procedure: total surgical time (ST), visualized follicles (VF), aspirated follicles (AF), recovered oocytes (RO), mean arterial pressure (MAP), heart rate (HR), respiratory rate (fR) and end tidal $\mathrm{CO} 2$ pressure $(\mathrm{EtCO} 2)$. Pre and postoperative arterial hemogasometry parameters $(\mathrm{PaO} 2, \mathrm{PaCO} 2, \mathrm{pH}$, $\mathrm{CHCO} 3$ and $\mathrm{BE}$ ) were also evaluated; and serum fibrinogen levels (SFL) on postoperative period. The values of VF, AF, RO, fR, $\mathrm{PaO} 2, \mathrm{pH}, \mathrm{CHCO} 3, \mathrm{BE}$ and $\mathrm{SFL}$ were similar between groups, although ST, $\mathrm{HR}, \mathrm{MAP}, \mathrm{EtCO} 2$ and $\mathrm{PaCO} 2$ were higher in LG. Regarding operative periods, $\mathrm{PaO} 2$ and $\mathrm{pH}$ were lower after surgery $(\mathrm{PaO} 2: 79.1 \pm 16.4 ; 79.2 \pm 11.7 \mathrm{mmHg} ; \mathrm{pH}: 7.30 \pm 0.09 ; 7.32 \pm 0.08)$ in both groups when compared to preoperative $(\mathrm{PaO} 2: 80.1 \pm 14.3 ; 83.4 \pm 10.5 \mathrm{mmHg} ; \mathrm{pH}: 7.38 \pm 0.05 ; 7.39 \pm 0.05)$ while $\mathrm{PaCO} 2$ $(43.6 \pm 4.6 ; 41.9 \pm 5.4 \mathrm{mmHg})$ and $\mathrm{CHCO} 3(22.8 \pm 1.5 ; 22.7 \pm 3.0 \mathrm{mmol} / \mathrm{L})$ increased $(\mathrm{PaCO} 2: 54.3 \pm 10.9$; $46.9 \pm 6.3 \mathrm{mmHg}$; $\mathrm{CHCO} 3: 24.8 \pm 3.4 ; 24.4 \pm 2.7 \mathrm{mmol} / \mathrm{L})$ postoperative. This alternative decubitus presented is a viable procedure and did not differ in oocyte recovery rates in ewes. However, entails cardiorespiratory major alterations compared to conventional procedure, making its practical applicability limited.
\end{abstract}

Keywords: ovine, surgery, biotechnology, genitourinary

\section{RESUMO}

O presente estudo teve como objetivo avaliar o acesso lateral direito como um método alternativo para a recuperação de oócitos por laparoscopia (LOPU) em ovelha. Vinte e quatro ovelhas Santa Inês foram distribuídas aleatoriamente em dois grupos com 12 animais: grupo RLD - posicionado em decúbito lateral direito, cefalodeclive com $10^{\circ}$ de inclinação; grupo $\mathrm{DD}$ - posicionado em decúbito dorsal em cefalodeclive, inclinação de $35^{\circ}$. Foram avaliados, a cada 10 minutos, durante o procedimento cirúrgico: tempo total da cirurgia (ST), folículos visualizados $(V F)$, folículos aspirados (AF), oócitos recuperados $(R O)$, pressão arterial média (MAP), frequência cardíaca $(F C)$, frequência respiratória (fR) e pressão final de CO2 (EtCO2). Também foram avaliados os parâmetros de hemogasometria arterial préoperatória e pós-operatória (PaO2, PaCO2, pH, CHCO3 e BE), bem como os níveis séricos de

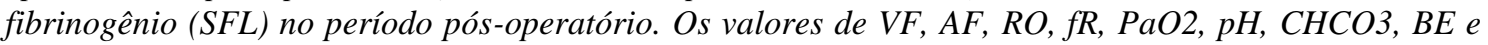

Recebido em 6 de outubro de 2017

Aceito em 25 de setembro de 2018

E-mail: renata_sgm@hotmail.com 
SFL foram semelhantes entre os grupos, embora ST, FC, MAP, EtCO2 e PaCO2 tenham sido maiores em RLD. Os parâmetros PaO2 e pH foram menores após a cirurgia (PaO2: 79,1 $\pm 16,4 ; 79,2 \pm 11,7 \mathrm{mmHg}$; pH: 7,30 $\pm 0,09 ; 7,32 \pm 0,08)$ em ambos os grupos em relação ao momento pré-cirúrgico (PaO2: $80,1 \pm 14,3 ; 83,4 \pm 10,5 \mathrm{mmHg} ; \mathrm{pH}: 7,38 \pm 0,05 ; 7,39 \pm 0,05)$, enquanto PaCO2 (43,6 $\pm 4.6 ; 41,9 \pm 5,4 \mathrm{mmHg}) \mathrm{e}$ CHCO3 (22,8 $\pm 1,5 ; 22,7 \pm 3.0 \mathrm{mmol} / \mathrm{L})$ aumentaram (PaCO2: 54,3 $\pm 10,9 ; 46,9 \pm 6,3 \mathrm{mmHg} ; \mathrm{CHCO}$ : $24,8 \pm 3,4 ; 24,4 \pm 2,7 \mathrm{mmol} / \mathrm{L})$ após a cirurgia. O decúbito lateral é uma alternativa viável para LOPU e não apresenta diferença para a taxa de recuperação oocitária em ovelhas. No entanto, promove alterações cardiorrespiratórias em comparação com o decúbito dorsal, tornando a sua aplicabilidade prática limitada.

Palavras-chave: ovino, cirurgia, biotecnologia, geniturinário

\section{INTRODUCTION}

Video-assisted laparoscopic ovum pick up (LOPU) is a minimally invasive procedure, with great importance in ovine and caprine reproductive biotechnologies. It allows oocytes recovery for in vitro embryo production and other techniques, enhancing herd reproduction (Cordeiro et al., 2014; Teixeira et al., 2013; Basso, 2008). Nevertheless, this procedure causes physiological alterations on cardiovascular and respiratory systems (Cohen $e t$ al., 2003), due to tilt head-down positioning and abdomen insufflation necessary for ovaries visualization and manipulation (Fischer et al., 1995).

Among physiological disorders related to this surgical technique it is worth mentioning the reduction of functional residual lung capacity and complacency, blood oxygenation, respiratory volume and cardiac output; increase in airway pressure, intra abdominal pressure (IAP), peripheral vascular resistance, central venous and arterial pressure, and imbalance on alveolar ventilation-perfusion relation (Chandrakanth and Talamini, 2001; Schauer, 2000; Kraut et al., 1999; Struthers e Cuschieri, 1998; Jorisj et al., 1993; Hayden e Cowman, 2011; Sharma et al., 1996).

Therefore, trying to mitigate cardiorespiratory changes caused by traditional LOPU, an alternative laparoscopic approach was developed, where the animal stays in lateral recumbency with a lower head-down inclination angle, hypothesizing that it would be possible to recover the same amount of oocytes, reducing large vessels and thorax compression, and consequently cardiovascular and respiratory adverse effects.

\section{MATERIAL AND METHODS}

All animal procedures were approved by Animal Ethics and Welfare Committee of the Faculty of Agricultural and Veterinary Sciences, Univ. Estadual Paulista "Júlio de Mesquita Filho", Jaboticabal, Brazil (protocol N 009761/13).

Animals were assigned to one of two groups: i) group RLD - positioned in right lateral decubitus, with $10^{\circ}$ head-down tilt; ii) group DD positioned in dorsal decubitus with $35^{\circ}$ inclination.

Twenty-four adult multiparous Santa Ines ewes, aged $3.1 \pm 1.1$ years, weighing $35.1 \pm 6.2 \mathrm{~kg}$ and exhibiting a mean body score of 3 (scale 1-5, Jefferies, 1961), were selected for this study, following clinical examination, blood analysis (hemogram, total proteins, fibrinogen and parasite control) and ultrasonography of the reproductive tract.

Briefly, animals were fasted then sedated with intramuscularly (IM) administration of chlorpromazine hydrochloride $(0.5 \mathrm{mg} / \mathrm{kg} \quad$ Clorpromazina ${ }^{\circledR}$, Uniao Quimica, Sao Paulo, Brazil) and tramadol hydrochloride $4 \mathrm{mg} / \mathrm{kg}$ (Cloridrato de Tramadol®, Hipolabor, Sabara, Brazil) combination. After 10min, jugular vein was catheterized using a $16 \mathrm{G}$ catheter (Angiocath-N®, BD, Brazil) and general anesthesia induced intravenously (IV) with ketamine $5 \mathrm{mg} / \mathrm{kg}$ (Dopalen ${ }^{\circledR}$ Sespo, Paulinia, Brazil) and midazolam $0.2 \mathrm{mg} / \mathrm{kg}$ (Dormire ${ }^{\circledR}$, Cristalia, Itapira, Brazil). Orotracheal intubation using a Magill $7,5 \mathrm{~F}$ endotracheal tube was performed and anesthesia maintenance using ketamine $10 \mathrm{mg} / \mathrm{kg} / \mathrm{h}$ and midazolam $0.2 \mathrm{mg} / \mathrm{kg} / \mathrm{h}$ diluted in $\mathrm{NaCl} 0,9 \%$ in constant infusion at $5 \mathrm{mg} / \mathrm{kg} / \mathrm{h}$. 
Surgical area was clipped and aseptically prepared using chlorhexidine gluconate $2 \%$. Surgical time was divided into five stages: skin incision (IN); first (P1), second (P2) and third (P3) laparoscopic portals introduction; right (O1) and left (O2) ovaries manipulation and aspiration; final cavity inspection, pneumoperitoneum withdrawal and dermorrhaphy (D). At each stage, times and complications were recorded.
In animals of DD, the surgical procedure was performed according to description of Mariano et al., 2015 (Figure 1 C e D), whereas in RLD surgical approach was made according to pilot study reported by Uscategui et al., 2014 (Figure 1 A e B). CO2 pneumoperitoneum was established with $5 \mathrm{mmHg}$ intra-abdominal pressure (IAP) at $5 \mathrm{~L} / \mathrm{min}$ flow rate. Atraumatic forceps (Babcock Forceps, 5mm, 36cm, Bhio Supply®, Esteio-RS, Brazil) were used for uterus, tubes, ovarian bursas, and ovaries manipulation.

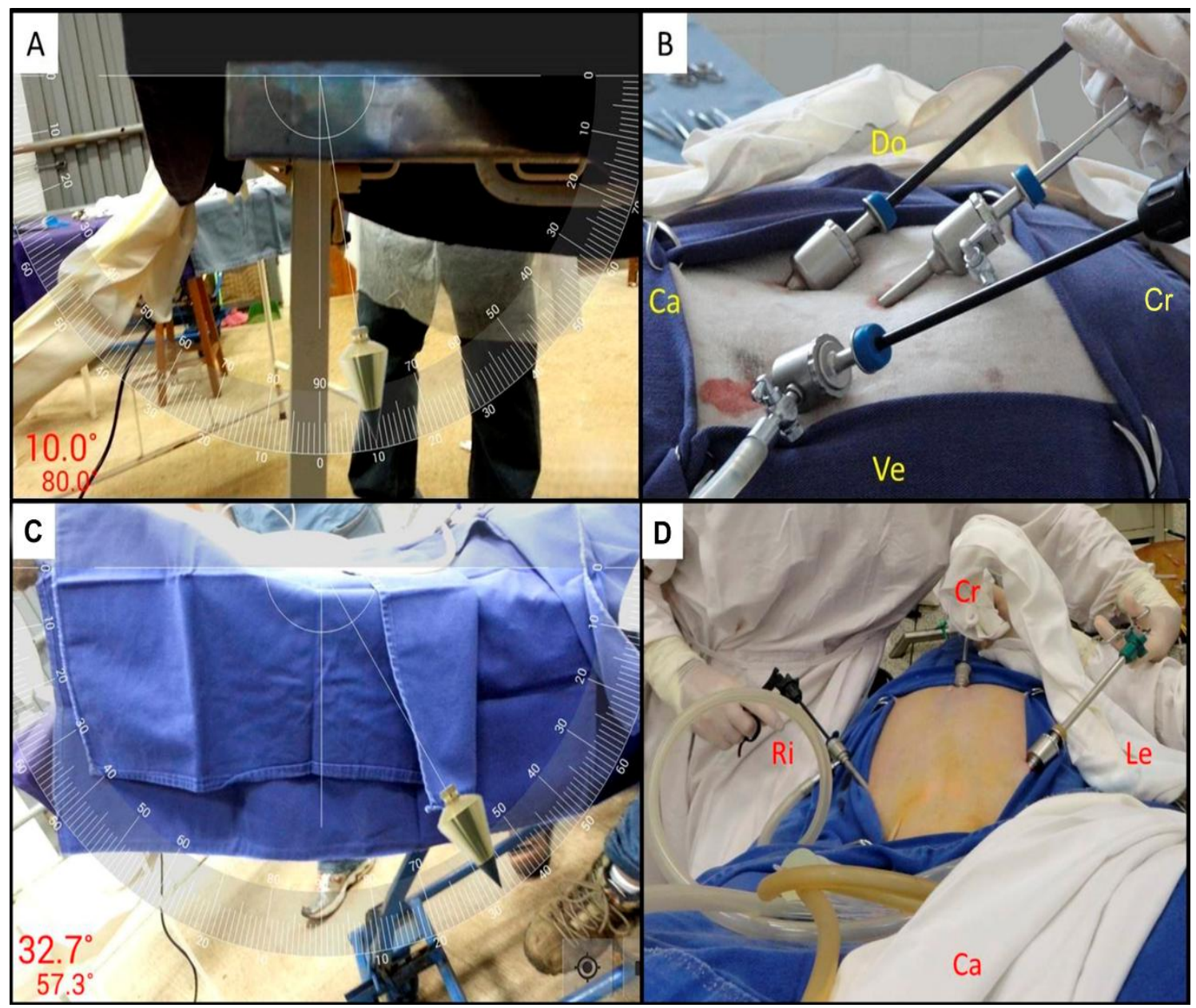

Figure 1. Laparoscopic ovum-pick up (LOPU) in Santa Ines ewe. In (A) and (B) patient positioning in lateral right decubitus and external view of the arrangement of laparoscopic portals in the caudal-cranial direction with the animal in supine position $\left(10^{\circ}\right)$. In (C) and (D), patient in dorsal position with the three laparoscopic portals and the animal in supine position $\left(32.7^{\circ}\right)$. 
Prior to follicular aspiration, ovaries were examined and number of follicles measuring 2 to $8 \mathrm{~mm}$ in diameter were recorded. Visualized follicles (VF), aspirated follicles (AF) and oocytes recovery (OR) were recorded as well. Retrieved oocytes were maintained in harvesting media (PBS supplemented with $10 \mathrm{IU} / \mathrm{mL}$ heparin at $36^{\circ} \mathrm{C}$ ) and conducted immediately to the laboratory, for observation and oocytes recovered counting in stereo microscope 40x magnification.

At LOPU final stages, ovaries were rinsed with sterile saline solution to remove clots from the ovarian surface in order to avoid the formation of postoperative adhesions. The trocars were removed, pneumoperitoneum completely drained and skin sutured. Surgical wounds were treated with chlorhexidine gluconate $2 \%$ followed repellent ointment application (Unguento Plus®, Pearson, Brazil). Post-surgical management was conventionally performed with antibiotics and painkillers use. Following surgery, animals were placed at a recovery room, observed until they were able to stand up unassisted. Furthermore, allocated at an experimental pen, with daily inspection, until clinical discharge.

Blood samples for hemogasometric evaluation were drawn from auricular artery through a puncture and heparinized syringe, which were immediately inserted into the hemogasometer (Omni-CTM®) Roche Diagnostics GmbH, Germany) after anesthesia induction and at the end of surgery. Partial pressure of oxygen $(\mathrm{PaO} 2$ in $\mathrm{mmHg}$ ), partial pressure of carbon dioxide ( $\mathrm{PaCO} 2 \mathrm{mmHg}$ ), oxyhemoglobin saturation $(\mathrm{SaO} 2$ in $\%)$, base excess (BE in $\mathrm{mmol} / \mathrm{L}$ ), bicarbonate concentration $(\mathrm{HCO} 3$ in $\mathrm{mmol} / \mathrm{L}$ ) and hydrogen potential $(\mathrm{pH})$ were analyzed as well.

Arterial pressure (MAP in $\mathrm{mmHg}$ ), heart (HR in bpm) and respiratory rate (fR in $\mathrm{rpm}$ ), end tidal $\mathrm{CO} 2$ tension $(\mathrm{EtCO} 2$ in $\mathrm{mmHg}$ ) and rectal temperature $\left(\mathrm{T}{ }^{\circ} \mathrm{C}\right)$ were measured every 10 minutes throughout the surgery.

Systemic inflammatory response was assessed by plasma fibrinogen concentration $(\mathrm{mg} / \mathrm{dL})$ measured by heat precipitation $\left(56^{\circ} \mathrm{C}\right)$ using a manual refractometer, during the preoperative period, immediately after and at 2, 4, 6, 8, 10, 12, 14 and 16 days following surgery.

Data were analyzed using $\mathrm{R}$ Software ${ }^{\circledR}$ ( R Foundation for Statistical Computing version 3.2.1, Vienna, Austria). Foundation for Statistical Computing, Austria). Normality distribution (Shapiro wilk test) and homoscedasticity of variance (Bartlett test) were tested for all variables. Surgical times, VF, AF, and OR were compared between groups by Student's test. Serum fibrinogen concentration, hematological and hemogasometric values and cardiorespiratory parameters were compared between groups by ANOVA and Tukey posthoc. Statistical significancewas declared at $\mathrm{P}<$ 0.05 .

\section{RESULTS}

Number of VF, AF and OR did not differ between groups ( $P>0.05)$. However, surgical time was longer in RLD, and throughout RLD procedure, ovarian manipulation was the most prolonged surgical step (Table 1).

Concerning to cardiorespiratory parameters was also observed that the lateral positioning resulted in an increased heart rate; mean arterial pressure and $\mathrm{EtCO} 2$, whereas there was no respiratory rate or surgical time by groups difference (Table 2)

No differences in $\mathrm{PaO} 2, \mathrm{SaO} 2, \mathrm{pH}, \mathrm{HCO} 3$ and $\mathrm{BE}$ were found between groups. However, $\mathrm{PaO} 2$ and $\mathrm{pH}$ decreased after surgery ended for both groups, resulting in below species normal range. An increase in $\mathrm{PaCO} 2$ and $\mathrm{CHCO} 3$ during postoperative period was observed, and $\mathrm{PaCO} 2$ was higher in RLD than DD at the same time (Table 3).

Serum levels of plasma fibrinogen were within the normal range for sheep, with no groups or surgical moment difference evaluated ( $\mathrm{P}>0.05)$. Furthermore, all animals had a satisfactory recovery from anesthesia and surgery, no complications were observed during postoperative monitoring until clinical discharge. 
Table 1. Mean \pm SE of the surgery time, VF, AF, CL and RO of Santa Inês ewes subjected to LOPU under general anesthesia, assessing surgical positioning in groups: DD and RLD

\begin{tabular}{lccc}
\multicolumn{1}{c}{ Parameters } & \multicolumn{2}{c}{ Surgical positioning } & \multirow{2}{*}{ P-Value } \\
\hline Duration of surgery (min) & DD & RLD & 0.040 \\
First ovary manipulation (min) & $14 \pm 2.0$ & $52 \pm 4.0$ & 0.049 \\
Second ovary manipulation (min) & $23 \pm 2.2$ & $18 \pm 2.6$ & 0.043 \\
VF & $11 \pm 1.2$ & $31 \pm 3.0$ & 0.250 \\
AF & $9 \pm 1.0$ & $9 \pm 1.5$ & 0.554 \\
CL & $0.8 \pm 0.2$ & $8 \pm 1.5$ & 0.294 \\
OR & $3.0 \pm 0.6$ & $28 \pm 0.7$ & 0.787 \\
\hline
\end{tabular}

Table 2. Mean \pm SE of cardiorespiratory parameters: HR, fR, MAP, EtCO2 and T of Santa Inês ewes subjected to LOPU under general anesthesia, evaluating the surgical positioning in groups: DD and RLD

\begin{tabular}{lccc}
\multicolumn{1}{c}{ Parameters } & \multicolumn{2}{c}{ Experimental groups } & \multirow{2}{*}{ P-value } \\
\hline $\mathrm{HR}(\mathrm{bpm})$ & DD & RLD & 0.013 \\
$\mathrm{fR}(\mathrm{rpm})$ & $98.3 \pm 3.3$ & $111 \pm 3.6$ & 0.176 \\
$\mathrm{MAP}(\mathrm{mmHg})$ & $36.7 \pm 2$ & $40.9 \pm 2.1$ & 0.009 \\
$\mathrm{EtCO} 2(\mathrm{mmHg})$ & $78 \pm 2.3$ & $87.4 \pm 2.6$ & 0.001 \\
$\mathrm{~T}\left({ }^{\circ} \mathrm{C}\right)$ & $37.3 \pm 1.2$ & $42.5 \pm 1$ & 0.230 \\
\hline
\end{tabular}

Table 3. Mean $\pm \mathrm{SE}$ of arterial hemogasometric parameters: $\mathrm{PaO} 2, \mathrm{PaCO} 2, \mathrm{SaO} 2, \mathrm{BE}, \mathrm{HCO} 3$ and $\mathrm{pH}$ of Santa Inês ewes submitted to LOPU under general anesthesia, assessing the surgical positioning in groups: DD and RLD

\begin{tabular}{lcccccc}
\multicolumn{1}{c}{ Parameter } & \multicolumn{2}{c}{ RLD } & \multicolumn{2}{c}{ DD } & $\begin{array}{c}\text { P-value } \\
\text { Group }\end{array}$ & $\begin{array}{c}\text { P-value } \\
\text { Moment }\end{array}$ \\
\hline $\mathrm{pH}$ & $7.38 \pm 0.05$ & $7.30 \pm 0.09$ & $7.39 \pm 0.05$ & $7.32 \pm 0.08$ & 0.695 & $<0.001$ \\
$\mathrm{PaO} 2(\mathrm{mmHg})$ & $80.1 \pm 14.3$ & $79.1 \pm 16.4$ & $83.4 \pm 10.5$ & $79.2 \pm 11.7$ & 0.691 & 0.557 \\
$\mathrm{PaCO} 2(\mathrm{mmHg})$ & $43.6 \pm 4.6$ & $54.3 \pm 10.9$ & $41.9 \pm 5.4$ & $46.9 \pm 6.3$ & 0.032 & $<0.001$ \\
$\mathrm{CHCO} 3$ & & & & & & \\
$(\mathrm{mmol} / \mathrm{L})$ & $22.8 \pm 1.5$ & $24.8 \pm 3.4$ & $22.7 \pm 3.0$ & $24.4 \pm 2.7$ & 0.797 & 0.033 \\
$\mathrm{SaO} 2(\%)$ & $92.7 \pm 3.5$ & $91.5 \pm 3.7$ & $92.1 \pm 2.2$ & $91.6 \pm 2.6$ & 0.752 & 0.341 \\
$\mathrm{BE}(\mathrm{mmol} / \mathrm{L})$ & $-0.81 \pm 1.4$ & $-0.37 \pm 2.5$ & $-1.84 \pm 2.2$ & $-0.99 \pm 2.3$ & 0.216 & 0.344 \\
\hline
\end{tabular}

\section{DISCUSSION}

The alternative laparoscopic approach provided an excellent reproductive organs access, manipulation and visualization. Number of follicles aspirated and oocytes recovered, which are crucial of this technique, did not differ between groups similarly as data reported by Stangl et al. (1999) in sheep hormonally untreated. Preliminary studies were conducted to evaluate the viability of laparoscopic side access to the uterus and ovaries in lateral decubitus position (Uscategui et al., 2014). Initially, the procedure were tried to perform in horizontal 
position with no inclination, although compromising reproductive organs manipulation, mainly due to rumen position, which strenuous uterine horns and ovaries visualization. The head-down $10^{\circ}$ inclination of animals was enough for side access LOPU performance (Figure 1A), as described by Allen (1996) who also emphasizes in reduction of iatrogenic injury risk during trocars introduction.

Normal cardiorespiratory function may be impacted because of recumbency positioning, head-down tilt, and pneumoperitoneum (Clarke et al., 2014; Hayden and Cowman, 2011). Furthermore, acidosis, hypercapnia, hypoxia, and bicarbonate concentration spurt were observed in both experimental groups as a procedure consequence. Induced pneumoperitoneum limits diaphragm movement, raises intrathoracic pressure (ITP), reduces complaisance and residual functional lung capacity, increases $\mathrm{CO} 2$ absorption and may results in atelectasis, ventilation-perfusion relationship imbalance, hypoxia and hypercapnia (Joris, 2009; Ferrão, 2016; Lemos et al., 2003; Duke et al., 1996).

Therefore, $\mathrm{PaCO} 2$ elevation is an expected result in this type of intervention (Hayden e Cowman, 2011; Gudmundsson e Heltne, 2004; Donaldson et al., 1998;) leading to respiratory acidosis (O'Learly et al., 1996; Hirvonen et al., 1995). $\mathrm{HCO} 3$ arterial blood concentration upsurge results from changes in blood $\mathrm{pH}$ and $\mathrm{PaCO} 2$ and was considered as compensatory measure of acid-basic imbalance (Haskins, 2015; Clarke et al., 2014), moreover similar results have been reported in sheep and humans who underwent to laparoscopy procedures (Lopes, 2014; Côrrea et al., 2008; Oliveira, 2005). Additionally, alteration described in spontaneous ventilated anesthetized ruminants was hypoventilation with hypercapnia (Campos and Roll, 2003; Wilson et al., 2000) and these effects could be controlled with positive pressure ventilation, however, studies are needed to confirm this assertion in lateral recumbency animals, moreover this measure is considered impractical to field in this type of patients.

We believe that performing side access LOPU needs head-down inclination and $\mathrm{CO} 2$ pneumoperitoneum, a slight inclination and lateral recumbency positioning can reduce diaphragmatic and great vessels compression, and consequently cardiorespiratory alterations. However, the animals in RLD showed greater alterations than DD (MAP, HR, $\mathrm{PaCO} 2$ and EtCO2 elevation).

Although only few studies evaluating lateral position for laparoscopic procedures are available (Hazebroek e Bonjer, 2006; Fujise et al., 1998; Mullet et al., 1993), in humans, scientific evidences suggest that laparoscopic procedures in lateral recumbency causes increased $\mathrm{CO} 2$ absorption, due to a higher amount of soft tissue exposed to gas. Consequently, vasodilation and sympathetic stimulation, tachycardia and hypertension occurs (Rassmussen et al. 1978), as evidenced in our results. Studies also reported that IAP increase causes vasoactive factors release, which leads hypertension and tachycardia, including normal partial arterial pressure values of CO2 (Punnonrn and Viinaniaki, 1982). Nevertheless, IAP established in both groups were the same, hemodynamic changes notable in RLD.

Lateral approach resulted in longer surgery time, caused by digestive tract presence in the surgical field. However, training and experience reduces surgery times (Teixeira et al., 2013), in this study initial phase side access LOPU took up to 74 minutes and at final stage this time fell to 34 minutes.

Some complications were observed, and there were no significant associations between position-related injuries. One ewe from the DG group died due to cardiorespiratory collapse, possibly by inadvertent intravenous $\mathrm{CO} 2$ insufflation, since autopsy revealed pulmonary ischemic injury. In LG, one rumen perforation during first trocar blind introduction, in this case surgical repair was performed without clinical consequences. Hayden and Cowman (2011) have described laparoscopic complications as common intercurrences.

As described by Meyer et al. (1995), high levels of fibrinogen indicate the existence of an inflammatory process, however, plasma fibrinogen levels were within the normal set values in sheep (Jain, 1993). Thus, we do not consider that the laparoscopic procedure induced inflammatory response, corroborating Teixeira $e t$ al. (2015) results in lambs subjected to laparoscopy. 


\section{CONCLUSION}

Side access LOPU technique is a viable procedure for oocyte recovery in Santa Inês ewes. However, entails cardiorespiratory major alterations compared to conventional procedure, making the practical applicability limited.

\section{ACKNOWLEDGEMENT}

The authors would like to thank São Paulo Research Foundation (FAPESP) [process 2013/09053-0] to the financial support. This study was financed in part by the Coordenação de Aperfeiçoamento de Pessoal de Nível Superior - Brasil (CAPES) - Finance Code 001.

\section{REFERENCES}

ALLEN, P.D. Anesthesia for minimally invasive surgery. In: LOUGHLIN, K.R.; BROOKS, D.C. Principles of endosurgery. Cambridge: Blackwell Science, 1996. p.54-71.

BASSO, A.C.; MARTINS, J.F.P.; FERREIRA, C.R. et al. Produção in vitro de embriões ovinos: aspectos da técnica de aspiração folicular e do tratamento hormonal de doadoras. Embrião, v.38, p.8-11, 2008.

CAMPOS, F.G.C.M.; ROLL, S. Complicações do acesso abdominal e do pneumoperitônio em cirurgia laparoscópica. Causas, prevenção e tratamento. Rev. Bras. Vídeocir., v.1, p.21-28, 2003.

CHANDRAKANTH, A.; TALAMINI, M.A. Current knowledge regarding the biology of pneumoperitoneum-based surgery. In: SOPER, N.J. Problems in general surgery. Philadelphia: Lippincott Williams \& Wilkins, 2001. p.52-63.

CLARKE, K.W.; TRIM, C.M.; HALL, L.W. Veterinary anaesthesia. 11.ed. London: Elsevier, 2014. p.135-137.

COHEN, R.V.; PINHEIRO FILHO, J.C.; SCHIAVON, C.A.; COFREA, J.L.L. Alterações sistêmicas e metabólicas da cirurgia laparoscópica. Rev. Bras. Vídeocir., v.2, p.77-81, 2003.
CORDEIRO, M.F.; TEIXEIRA, P.P.M.; OLIVEIRA, M.E.F. et al. Reproductive efficiency of adult and prepurbetal goats subjected to repeated folicular aspiration. Arq. Bras. Med. Vet. Zootec., v.66, p.137-144, 2014.

CORREA, C.M.O; BRANDAO, M.J.N.; HIRATA, E.S.; UDESLSMANN, A. Considerações anestésicas na cirurgia laparoscópica. Arq. Bras. Cir. Dig., v.21, p.136$138,2008$.

DONALDSON, L.L.; TROSTLE, S.S.; WHITE, N.A. Cardiopulmonary changes associated with abdominal insufflation of carbon dioxide in mechanically ventilated, dorsally recumbent, halotane anaesthetized horses. Equine Vet. J., v.30, p.144-151, 1998.

DUKE, T.; STEINACHER, S.L.; REMEDIOS, A.M. Cardiopulmonary effects of using carbon dioxide for laparoscopic surgery in dogs. Vet. Surg., v.25, p.77-82, 1996.

FERRÃO, I.M.R.D. Estabelecimento do pneumoperitoneu para laparoscopia em canídeos: estudo comparativo de três técnicas. 2016. Dissertação (Mestrado em Integrado em Medicina Veterinária) - Faculdade de Medicina Veterinária, Universidade de Lisboa, Lisboa, POR.

FISCHER, A.T.J.R.; VACHON, A.M.; KLEIN, S.R. Laparoscopic inguinal herniorrhaphy in two stallions. J. Am. Vet. Med. Assoc., v.207, p.1599601, 1995.

FUJISE, K.; SHINGU, K.; MATSUMOTO, S. et al. The effects of the lateral position on cardiopulmonary function during laparoscopic urological surgery. Anaesth. Anal., v.87, p.925930, 1998.

GUDMUNDSSON, F.F.; HELTNE, J.K. Respiratory changes during prolonged increased intra-abdominal pressure in pigs. Acta Anaesthesiol. Scand., v.48, p.463-468, 2004.

HASKINS, S.C. Monitoring anesthetized patients. In: LUMB \& JONES Veterinary anesthesia and analgesia. Ames, Iowa: WileyBlackwell, 2015. p.86-113. 
HAYDEN P.; COWMAN S. Anaesthesia for laparoscopic surgery. Cont. Educ. Anesth. Critical Care Pain, v.11, p.177-180, 2011.

HAZEBROEK, E.J.; BONJER, H.J. Effect of patient position on cardiovascular and pulmonary function. In: WHELAN, R.L.; FLESHMAN, J.W.; FOWLER, D.L. (Eds.). The sages perioperative care in minimally invasive surgery. New York: Springer, 2006. 410p.

HIRVONEN, E.A.; NUUTINEN, L.S.; KAUKO, M. Hemodynamic changes due to Trendelenburg positioning and pneumoperitoneum during laparoscopic hysterectomy. Acta Anaesthesiol. Scand., v.39, p.949-995, 1995.

JAIN, N.C. Essentials of veterinary hematology. Philadelphia: Lea \& Febiger, 1993. 417p.

JORIS, J.L.; NOIROT, D.P.; LEGRAND, M.I.; JACQUET, N.J; LAMY, M.L. Hemodinamic changes during laparoscopic cholecystectomy. Anesth. Analg., v.76, p.1067-1071, 1993.

JORIS JL. Anaesthesia for laparoscopic surgery. In: Text Book of Anaesthesia. 7th ed. Elsevier Health Sciences. p. 2185-2202, 2009.

KRAUT, J.K.; ANDERSON, J.T.; SAFWAT, A.; BARBOSA, R.; WOLFE, B.M. Impairment of cardiac performance by laparoscopy in patients receiving positive end expiratory pressure. Arch. Surg., v.134, 76-80, 1999.

LEMOS, S.L.S., VINHA, J.M., SILVA, I.S. et al. Efeitos do pneumoperitônio com ar e $\mathrm{CO} 2$ na gasometria de suínos. Acta Cir. Bras., v.18, 445$451,2003$.

LOPES, M.C.S. Achados clínicos, hemodinâmicos e hemogasométricos da infusão contínua de propofol associado ou não ao tramadol em ovelhas submetidas à videolaparoscopia. 2014. 108f. Tese (Doutorado Cirurgia Veterinária) - Universidade Estadual Paulista Júlio de Mesquita Filho, Faculdade de Ciências Agrárias e Veterinárias de Jaboticabal, Jaboticabal, SP.

MARIANO, R.S.G.; USCATEGUI, R.A.R.; NOCITI, R.P. et al. Intraperitoneal lidocaine hydrochloride for prevention of intraperitoneal adhesions following laparoscopic genitourinary tract surgery in ewes. Vet. Med., v.60, p.403-406, 2015.
MEYER, D.J.; COLES, E.H.; RICH, L.J. Medicina de laboratorio veterinária: interpretação e diagnóstico. São Paulo: Roca, 1995. p.47-61.

MULLETT, C.E.; VIALE, J.P.; SAGNARD, P.E. et al. Pulmonary $\mathrm{CO} 2$ elimination during surgical procedures using intra- or extraperitoneal $\mathrm{CO} 2$ insufflation. Anaesth. Analg., 1993, v.76, p.622-626.

O'LEARY, E.; HUBBARD, K.; TORMEY, W.; CUNNINGHAM, A.J. Laparoscopic cholecystectomy: hemodynamic and neuroendocrine responses after pneumoperitoneum and changes in position. $\mathrm{Br}$. J. Anaesth., v.77, p.640-644, 1996.

OLIVEIRA, C.R.D. Anestesia para cirurgia videolaparoscópica. Rev. Bras. Videocir., v.3, p.32-42, 2005.

PUNNONRN, R.; VIINANIAKI, O. Vasopressin release during laparnscopy: role of increased intra-abdominal pressure. Lancet, v.1, p.175-176, 1982.

RASMUSSEN, J.P.; DAUCHOT, P.J.; DEPALMA, R.G. et al. Cardiac function and hypercarbia. Arch. Surg., v.113, p.1196-2000, 1978.

SCHAUER, P.R. Physiologic consequences of laparoscopic surgery. In: EUBANKS, W.S.; SWANSTROM, L.L.; SOPER, N.J. Mastery of laparoscopic surgery. Philadelphia: Lippincott Williams \& Wilkins, 2000. p.22-38.

SHARMA, K.C.; BRANDSTETTER, R.D.; BRENSILVER, J.M. Cardiopulmonary physiology and pathopysiology as a consequence of laporoscopic surgery. Chest, v.110, p.810-815, 1996.

STANGL, M.; KÜHHOLZER, B.; BESENFELDER, U.; BREM, G. Repeated endoscopic ovum pick-up in sheep. Theriogenology, v.52, p.709-716, 1999.

STRUTHERS, A.D.; CUSCHIERI, A. Cardiovascular consequences of laparoscopic surgery. Lancet, v.15, p.568-570, 1998. 
TEIXEIRA, P.P.M.; PADILHA, L.C.; LIMA DA SILVA, A.S. et al. Ovum pick-up technique in recently weaned ewe lambs subjected to ovarian stimulation. Acta Sci. Vet., v.43, p.1-9, 2015.

TEIXEIRA, P.P.M.; PADILHA, L.C.; MARIANO, R.S. et al. Aspiração folicular. In: OLIVEIRA, M.E.F.; TEIXEIRA, P.P.M; VICENTE W.R.R. Biotécnicas reprodutivas em ovinos e caprinos. São Paulo: MedVet, 2013. $305 \mathrm{p}$.
USCATEGUI, R.; GOMES MARIANO R. S.; PERECIN NOCITI, R. et al. Side access lopu in sheep-pilot study. Reprod. Dom. Anim., v.49, p.90-90, 2014.

WILSON D.V., KANTROWITZ A., PACHOLEWICZ J. Perioperative management of calves undergoing implantation of a left ventricular assist device. Vet. Surg., v.29, p.106$118,2000$. 